\title{
Parenting Culture of Low-Income Families in Implications for the Subjective Well-being of Early Childhood Students
}

\author{
Sri Wahyuni 1, Azlin Atika Putri², Reswita3 \\ DOI: 10.35445/alishlah.v13i3.968
}

\begin{abstract}
Article Info
Abstract

Keywords:

Parenting Culture;

Low-income Families;

Subjective Well Being;

Early Childhood;

Education

Poverty has a negative impact on parenting patterns that can reduce the subjective well-being) of childhood. This study aims to reveal the parenting skill of low-income families to improve the subjective well-being of childhood. This type of descriptive research with 119 parents in Pekanbaru comes from lowincome families who live in Pekanbaru. Results of the study revealed parenting skills respondents (41\%) require information about good parenting to develop the potential of children for the child's positive development, the child's goodness, and independence. While $22 \%$ want their children to be successful and have a better future, they do not use the correct method, and $18 \%$ of respondents want their children to be more normative, more obedient, have good habits, and be accepted by society. About $14 \%$ of respondents want their children to achieve better academic performance, and $5 \%$ want their children to be happy and happy later. The conclusion is Parenting skills of low-income families in improving subjective well-being of early childhood is not optimal.
\end{abstract}

Kata kunci:

Budaya Asuh;

Keluarga Miskin;

Kebahagiaan;

Kesejahteraan Subjektif;

Anak Usia Dini;

Pendidikan

\begin{abstract}
Abstrak
Kemiskinan memberikan dampak negatif pada pola pengasuhan anak. Kemiskinan tersebut dapat mengurangi kesejahteraan subjektif (kebahagiaan yang dirasakan secara pribadi) anak. Penelitian ini bertujuan untuk mengungkap bagaimana keoptimalan budaya asuh pada keluarga miskin dalam rangka meningkatkan kesejahteraan subjektif anak di Kota Pekanbaru. Jenis penelitian ini menggunakan pendekatan deskriptif dengan sampel berjumlah 119 orangtua yang tersebar pada tiga kecamatan di Kota Pekanbaru. Hasil penelitian mengungkapkan keterampilan pengasuhan mayoritas responden (41\%) membutuhkan informasi budaya asuh yang baik untuk mengembangkan potensi anak, demi perkembangan anak yang positif, kebaikan anak itu sendiri dan kemandiriannya. Sementara 22\% ingin anaknya suksesnamun tidak menggunakan cara yang benar dan $18 \%$ responden menginginkan agar anaknya lebih normatif, lebih patuh, memiliki kebiasaan baik dan dapat diterima masyarakat. Sekitar $14 \%$ responden menginginkan anaknya meraih prestasi akademik yang lebih baik, dan $5 \%$ responden ingin agar anaknya bahagia serta dapat membahagiakannya kelak. Kesimpulannya adalah budaya asuh yang dilakukan oleh keluarga miskin kepada anak usia dini dalam rangka meningkatkan kesejahteraan subjektifnya belum optimal.
\end{abstract}

\footnotetext{
${ }^{1}$ Universitas Lancang Kuning, Pekanbaru, Indonesia

Email: sriwahyuni91@unilak.ac.id

2 Universitas Lancang Kuning, Pekanbaru, Indonesia

Email: azlin@unilak.ac.id

3 Universitas Lancang Kuning, Pekanbaru, Indonesia

Email: reswita@unilak.ac.id
} 


\section{INTRODUCTION}

One measure of a prosperous life is a decent life, fulfilling the needs of life and feeling psychologically happy. The dominant factor affecting the welfare of life is economic problems (McCormick, 2017). Many economically disadvantaged families (poor families) in Indonesia, especially in Riau, need the government's alleviation. According to (Nurwati, 2008)poverty can be interpreted as a condition where a person, family, or community member cannot meet their normal needs as other members of society in general. This poverty needs to be understood the factors that cause it and need to think about strategies to overcome it (Prawoto, 2008).

Poverty in the city of Pekanbaru exceeded the national average in 2019, where the poverty rate touched the level of $11.98 \%$ (Badan Pusat Statistik, 2019). The poor population in Riau Province in 2019 was 397.9 thousand (8.05\%), for Pekanbaru City as much as 5.30\%, while the poverty index for Pekanbaru city reached $0.24 \%$ (Mizkan et al., 2015). This condition is very concerning and requires serious efforts to reduce/reduce the poverty rate. Poverty will affect various aspects of the life of the people concerned. Poverty itself is identical with the population's education level, which is still low on average. There is an increase in unemployment which will encourage continued poverty of the population (Suryawati, 2005). Furthermore, research (Mahyatun, 2019) with the title of a scientific study on the role of the family in children's growth concluded, especially regarding children's growth education, obtained factual data that $57 \%$ of parents in the village environment did not care about their children's education.

The Pekanbaru City Government has carried out various poverty alleviation programs. However, these efforts have only touched the physiological handling of poverty, while psychological treatments such as family-based alleviation have not been optimally carried out. This family-based treatment is carried out by various methods, including providing business capital, education, and knowledge about the functioning of parenting in the family to help children achieve their happiness (Departemen Sosial RI, 2005). Improving the quality of parenting culture in low-income families can directly improve children's subjective well-being from these families. Subjective well-being itself has many positive benefits for life, such as health. Prosperous individuals tend to have better physical health than poor individuals (Koivumaa-Honkanen et al., 2001) and avoid health-damaging behaviors such as smoking, consuming alcohol, and committing suicide (Valois et al., 2004). Parenting culture is defined as caring for children until they grow up (Santrock, 2003), also called how to treat children (Steinberg, 2005). Another definition mentions it as a way of training and educating (Elisabet, 2010). (Crider, 1981) providing guidance and direction, praise, a sense of security, and attention to children is defined as a parenting style. In essence, parenting culture is the ways parents care of, raise, treat, communicate, guide, direct, pay attention, express the affection and sense of security (physical and non-physical) that parents give to their children, which shape the child in such a way.

Subjective well-being or subjective well-being is often abbreviated as SWB (Diener et al., 2000), is a form of happiness that emphasizes pleasant emotional experiences. This involves a high status of positive affect and low negative affect on a person. It means that prosperous individuals experience more positive affect than negative affect in their lives. Someone more dominantly experiences pleasure, happiness, and satisfaction than feelings of sadness, disappointment, and dissatisfaction. Such conditions are experienced by children who have good subjective well-being and vice versa. According to (Kahneman \& Krueger, 2006), the dominant factors influencing subjective well-being are personality, context and situation, demographic variables, environment, economy, and coping strategies.

This subjective approach to happiness assumes that people from various cultures feel comfortable focusing individualistic measurements on individual feelings and satisfaction. It would be more appropriate if the measurement involved individual analysis (Diener et al., 2009). Thus the measure of happiness is very subjective/individual and cannot be generalized because many aspects 
affect the meaning of happiness (Fuad, 2017). It can be said that subjective well-being is a person's subjective assessment of his life as a whole. Understanding of the concept focuses on understanding happiness as life satisfaction. According to (Camfield et al., 2009), the psychological approach, subjective well-being emphasizes fulfilling a person's needs and expectations related to the dimensions of his childhood experience. Family, as stated by (Fomby \& Cherlin, 2007), is a multidimensional concept. Then according to (Fatkhurohmah et al., 2019), the family is a social group whose group members live together, there is cooperation in economic and financial terms, and regeneration or reproduction occurs. The family is a place to get attention and affection for children in general, but in reality, not all children get it.

This situation is influenced by many aspects, such as parents' ignorance about good parenting, parents' busyness so that their time is very limited to pay attention to their children, parents of Alternative Parenting Models in Dual-Career Family (Hidayati, 2016) economic conditions that make parents unable to meet their material needs. What their children need includes pocket money or shopping money when going to school, and others. This means that family is not the only source of happiness for every child. These conditions research to reveal the culture of parenting in low-income families needs to be done because it is directly related to the emotional welfare of children, which is indirectly the basis of the government's foothold in the preparation of a complete poverty alleviation program. Based on the background and literature review above, the problem can be formulated to achieve the research objectives, namely, how the parenting culture in low-income families has implications for the subjective well-being of early childhood.

\section{METHOD}

This research is a descriptive type of research that reveals or describes how the culture of fostering by low-income families improves the subjective welfare of children in Pekanbaru City. The population in this study is all poor people who live in Pekanbaru City. The choice of research location was based on the high poverty rate in three sub-districts in Pekanbaru City, namely Tampan District, Tenayan Raya District, and Rumbai District. Mechanical taking the sample that is used is random cluster sampling. Steps to be taken in determining the sample using techniques: Determining the characteristics of the poor population in Pekanbaru City who has children aged early (o-8 Years), Determining each cluster, which is the poor who live in the area Penggiran city. In this way, three sub-districts were obtained, and the poor in the three sub-districts were taken randomly as research respondents.

Criteria low-income families used for the withdrawal of samples used criteria are expressed by (Wahyuni \& Reswita, 2018), namely: Level of education of parents up to the level of high school, Revenue in under Wage Minimum Average (UMR) The city of Pekanbaru, namely Rp. 2,100,ooo, and the type of place to stay semi-permanent, renting and adjusted to the facts in the field. The total number of subjects involved was 119 people obtained from Tampan district 35 people (29\%), Tenayan Raya 43 people (36\%) and Rumbai 41 people (35\%). The distribution can be seen in the following image:

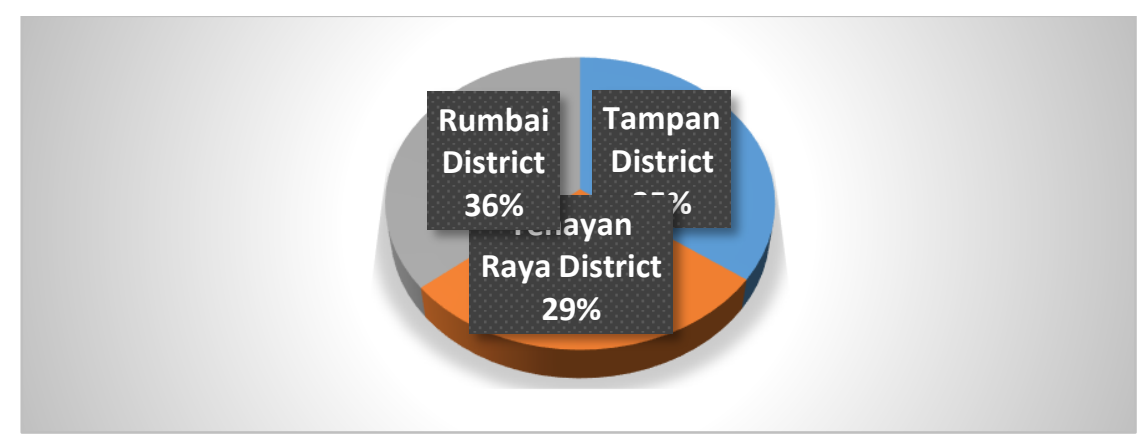

Figure 1. Distribution of Subjects by Research Area 
The level of parental education as the subject is described separately between father and mother. The father's education level mainly was junior high school graduates (34\%) followed by the elementary school (28\%), high school (22\%), no school/not finished elementary school (4\%), bachelor degree (2\%) and diploma (1\%). The mother's education level is also not different from the father's average level of education. As many as 39\% of mothers graduated from junior high school, 29\% completed high school, and 25\% finished elementary school. Mothers with higher education only amount to $1 \%(\mathrm{~S} 1)$, while those who do not go to school are around $6 \%$.

The type of work of the respondents' parents is primarily farmers and laborers. Some of them even work as scavengers. Father's occupation varies. Most are Farmer/Fisherman (39\%), followed by labor (17\%), small trader (15\%), driver (8\%), handyman (4\%), firewood seeker/scavenger (2\%) and do not have a job (3\%). Can be seen in the following image :

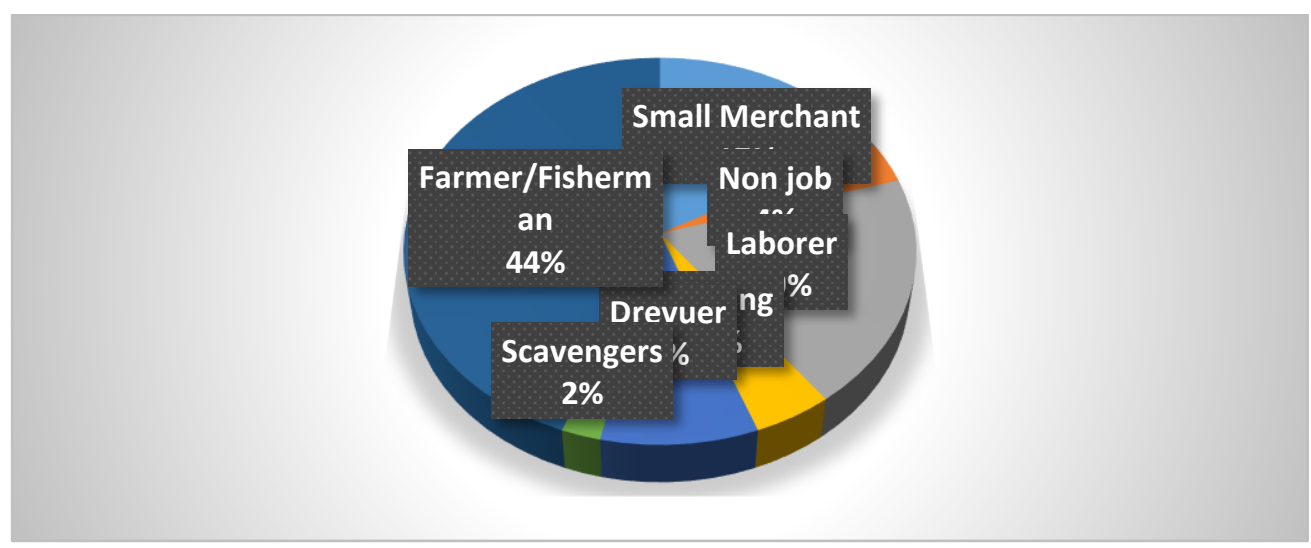

Figure 2. Father's occupation

While mothers' work is generally dominated by housewives (82\%) and only a few, have professions that generate income for the family. As many as $4 \%$ of women are small traders, and some women are firewood scavengers/scavengers (2\%), farmers (2\%), and tailors (2\%).

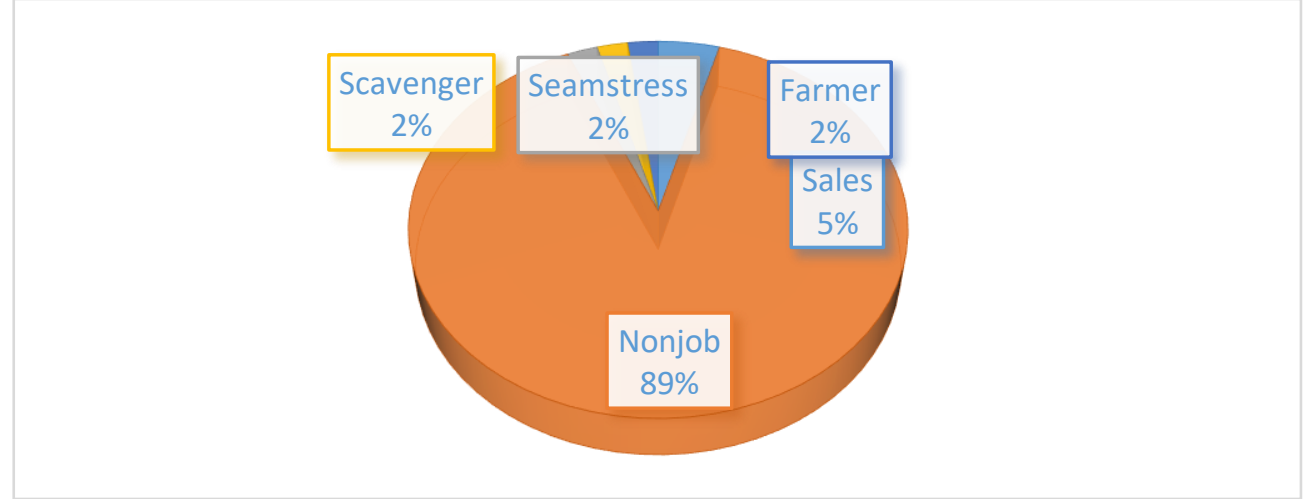

Figure 3. Mother's Work

There are also 119 child subjects involved in the study. $47 \%$ female, $53 \%$ male. The education level of Early Childhood Education to Elementary School Class 1 (o - 8 years ). Subjects many as 10 people (9\%), SD Class 1 as many as 19 people (16\%), and not the school as much as 90 people (75\%). More details can be seen in the image : 


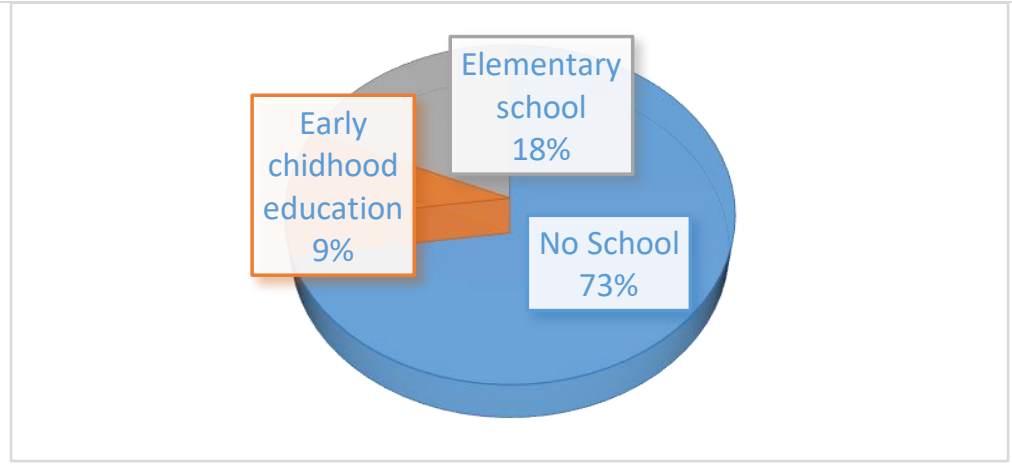

Figure 4. Children's Education Level

Data analysis was carried out qualitatively by interpreting each subject's answer to be coded and categorized based on specific groups according to the type of question because the data collection process turned out to take quite a long time until now, the data analysis process has only arrived at the interpretation of the subject's answers and has not been completed.

The level of parental education as the subject is described separately between father and mother. The father's education level was mostly junior high school graduates (34\%) followed by the elementary school (28\%), high school (22\%), no school/not finished elementary school (4\%), bachelor degree (2\%) and diploma (1\%). The mother's education level is also not different from the father's average level of education. As many as $39 \%$ of mothers graduated from junior high school, 29\% completed high school, and 25\% finished elementary school. Mothers with higher education only amount to $1 \%(\mathrm{~S} 1)$, while those who do not go to school are around $6 \%$.

Questionnaires were used to be open (open-ended questionnaire). Guidelines for the questionnaire are format stuffing, power collecting the data respondents research ( parents and children ), and then writing it in the interview format. When still no answer to that is not the focus/not clear collecting the data inquire more about the respondent. The person collecting the data carried by two people is the same in every family to obtain accurate data. Approach Qualitative used to gather information about the parenting culture enforced by a low-income family using open (open-ended questionnaires). A quantitative approach is used to measure the level of subjective wellbeing of children. Outcomes are generated in the form of information about the forms of culture custody, problems psychosocial in culture custody as a result of poverty, and the baseline of wellbeing subjectively child.

\section{FINDINGS AND DISCUSSION}

The ability of parenting can be seen from the accuracy in describing the child's condition. According to the parents of each following, is the result of the depiction conditions for children.

\section{Children's intelligence and parents' assessment of children's intelligence}

Based on the survey results, it was found that approximately $46 \%$ of parents described their children's intelligence as average or average. Meanwhile, $43 \%$ of parents describe their children as intelligent, and only $11 \%$ describe them as less intelligent. 


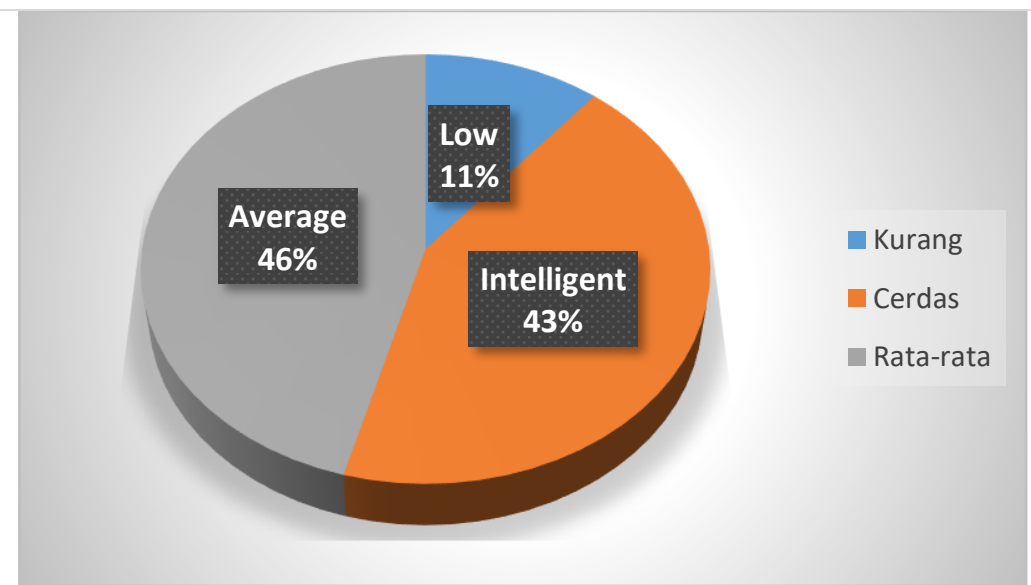

\section{Figure 5. Parents' Description of their Children's Intelligence}

The assessment used by parents to describe the intelligence is generally ranked in class (50\%) such as class champion, top ten, middle rank, never/never stayed in class. Parents' assessments are also based on the category of report cards (30\%), such as high, medium, or low scores. However, $20 \%$ of parents use their observations of their children's learning behavior, such as eager/lazy to learn, behaving intelligently or finding intelligently, or finding it challenging to catch lessons at school.

\section{Children's general emotions and parents' understanding of children's emotions}

Besides providing an overview of children's intelligence, parents are also required to understand the general picture of children's emotions. Based on the survey results, it is known that almost all parental subjects describe their children's emotions as positive emotions (93\%), and only a few describe their children's emotions as negative (7\%).

Parents are also asked to explain what things make their children feel happy. The results show that freedom (27\%), such as being allowed to play, being free to watch television, and being followed by one's will, are things that children like. Furthermore, what parents perceive can please their children is playing activities (25\%), playing with younger siblings, playing with friends, and just playing. According to parents (24\%), children will also be happy if they get the desired material such as pocket money and buy (something) they like. Furthermore, children are also perceived as $12 \%$ of parents like tourism, such as being invited for a walk and eating good food (culinary tourism). A small proportion of parents (6\%) said that the primary positive relationship with parents and family is the reason why children feel happy such as gathering with family, and (unfortunately) there is a category of "not being scolded. Finally, $6 \%$ of parents say that their children will feel happy if they get achievements in the academic field, both when they get achievements and when doing learning activities.

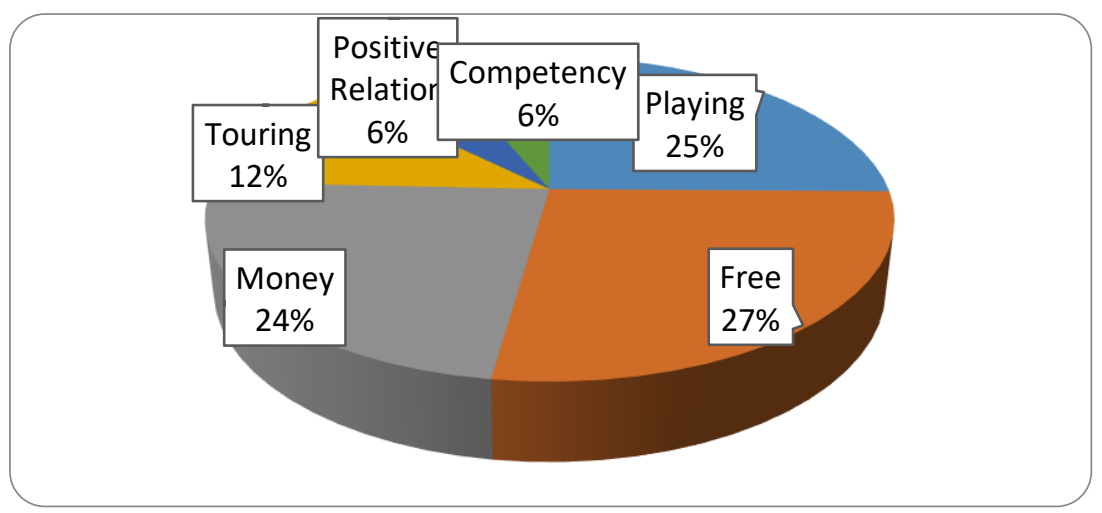

Figure 6. Children's Emotions 
Understanding the child also requires parents to know what brings up negative emotions in their children, sadness. From 119 subjects, 115 answers are relevant to the question. Most of the subjects perceive that their children's negative emotions arise if they experience problematic relationships (43\%) such as: being scolded by authority figures, both by parents and siblings, and when experiencing arguments, either with siblings (brothers and sisters) or with friends. Furthermore, about $40 \%$ of parents reported that the thing that triggers their children's negative emotions is frustration, namely, a condition where the child's desire gets inhibited. Examples of situations include when the child does not get what he wants, does not have money (to buy something), cannot eat snacks (can eat something). so because they have no money), or because they are prohibited from playing. As many as $7 \%$ of children admitted that they were sad because of the separation from their parents, some of whom had lost their father due to leaving or died. At the same time, theoretical value is recognized as a factor that causes sadness for $4 \%$ of the subjects. Being given a task and feeling sick is perceived by $3 \%$ of parents as the cause of their child's sadness.

\section{Children Behavior and Culture foster that applied Parents}

Parents were also asked to describe how the child behaved, such as obedience, manners, and activity level. Compliance describes children's behavior in responding to orders from parents, manners, or manners more to the normative behavior of children in their interactions with parents. At the same time, the activity level refers to the activities that children do in their spare time. Regarding obedience, almost all parents (79\%) described their children's behavior as obedient, and only $19 \%$ said their children tended to be challenging to manage. In comparison, another $2 \%$ said they were sometimes obedient and sometimes not.

When further asked how parents shape their children's obedience, 110 parents stated that most parents rely on giving their children advice/advice (40\%) as cognitive input. As many as $31 \%$ of parents use behavior formation techniques such as habituation, being taught the details of behavior that must be done, and giving responsibility to children to do something. Not a few parents (24\%) used coercion techniques by emphasizing prohibitions, forcing, and giving punishment by scolding if the child disobeyed his orders. Several parents (5\%) said they did not need any effort to control their child's behavior because they thought their child did not exhibit behavior they did not like.

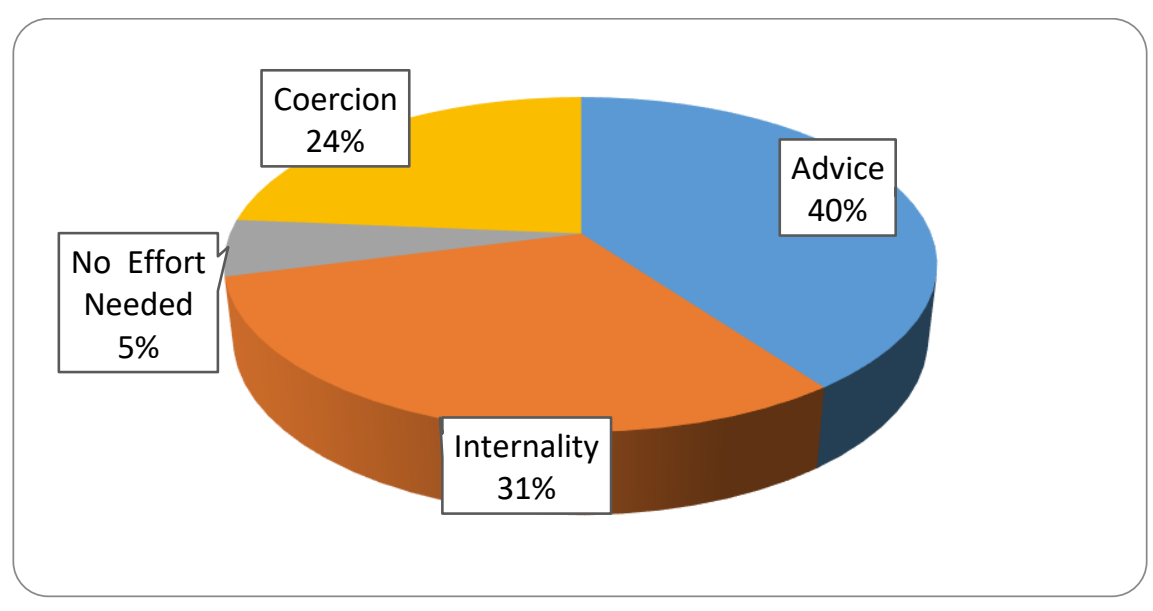

Figure 7. Overview of Child Behavior

Regarding normative behavior or child manners, $88 \%$ of parents describe their child's behavior as polite, while $10 \%$ of parents sometimes say polite and sometimes disrespectful; disrespectful behavior is usually shown when the child is frustrated. Only $2 \%$ of parents said that their children were not polite, mainly seen from the frequency of swearing/obscenities. Slightly 
different from forming children's obedience, parents use more formation techniques (42\%). Meanwhile, around 34\% of respondents gave advice/suggestions as cognitive input by providing explanations and advice. Regarding the enforcement of good manners, parents did not even hesitate to give coercion (24\%) such as warning, scolding, and even giving physical punishment.

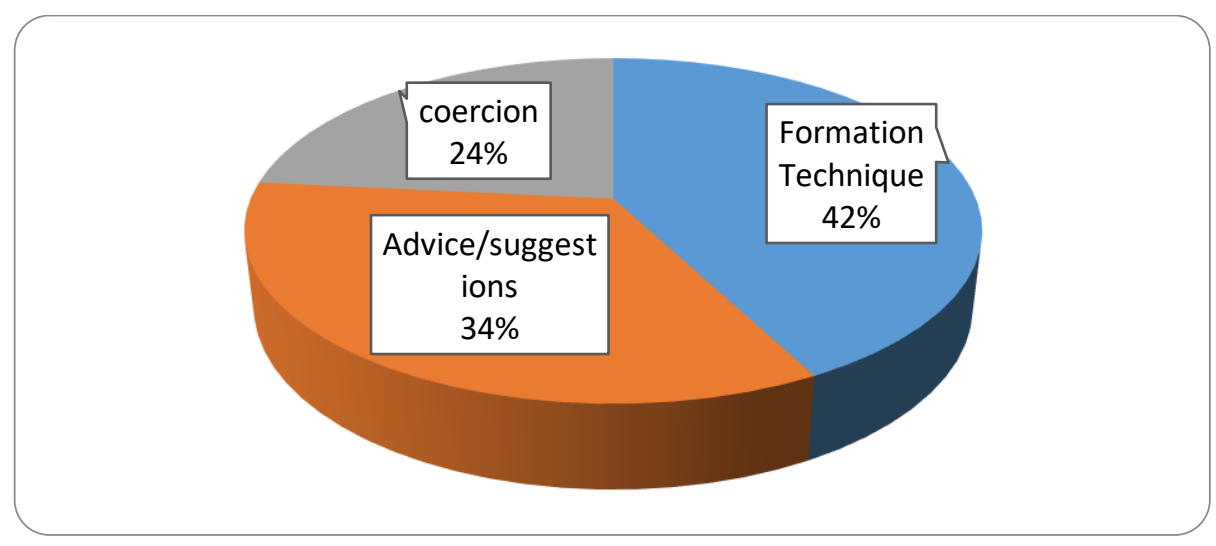

\section{Figure 8. Forming Children's Politeness}

Regarding children's level of activity in carrying out activities in their spare time, almost all parents describe their children as active children (89\%). However, around $11 \%$ of parents feel that their children are not as active as other children. The activities carried out by children include playing (46\%), playing alone or playing with friends, helping parents (37\%), including helping to earn a living, taking care of younger siblings, and helping with household chores. Only a subset of children (17\%) described their parents as liking cognitive activities such as learning and being creative on their own.

\section{Overview of Children's Social Behavior}

Parents were also asked to describe their child's social behavior in their environment by answering questions about whether the child seemed to have many friends and the types of activities he often did with his friends. Almost all children (93\%) are involved with social interactions in their environment. Only $5 \%$ of children, according to their parents, do not like interacting, and $2 \%$ even reported not liking social interaction activities with their environment.

The game activities carried out by children with their friends include traditional games such as plays (a kind of hide and seek), forts, playing ball, and other games have done together. Some children prefer to play alone (4\%) while $2 \%$ of children can access modern/digital games, for example, borrowing a tablet from their neighbor. Unfortunately, about $6 \%$ of parents admit that they do not know their children when playing outside the house.

\section{Parenting Skills}

The first question about parenting skills reveals how important it is for parents to know information about their child's development. All respondents said that information about child development is essential, although respondents have different reasons. The majority of respondents (41\%) need this information to develop the child's potential, for the child's positive development, the good of the child himself, and his independence. While $22 \%$ want their children to be better times in the future, $18 \%$ of respondents wanted him to be more normative, more compliant, have good habits, and be socially acceptable. Around $14 \%$ of respondents want their children to achieve better academic achievements, and $5 \%$ of respondents want their children to be happy and make them happy in the future.

The descriptive analysis results showed that parents' parenting skills in terms of their level of knowledge about their children's condition were not optimal. However, most of the children who were the sample of the study had high subjective well-being. This shows that subjective well-being is 
not only measured by the socioeconomic level of the family. Family lot or a little is not a factor of decisive, subjective welfare of children is defined as the meaning of life, such as life satisfaction, positive affect is high, and the lack/absence of negative affect (Dambi et al., 2016). Even in the case of children who do not have parents (orphans), the satisfaction of living is high. This evidence is from Yuniana's (2011) results about the well-being subjective to the fatherless motherless.

Parents' financial situation will influence students' happiness because they can fulfill their needs such as food, clothing, pocket money, learning facilities, and so on. It is supported by the results of the study (Taufiq, 2012) utilization of spare time a kid who comes from a low-income family greatly influenced by alive his. Children who have free time and can use it well show that their life is meaningful. To make this happen, children need support from the environment in which they live. Elisabet (2010) states that high social value is emphasized on popularity, so people will feel happy if they have the opportunity to have social relationships. Family plays an important as supporting the satisfaction of the child in particular who come from families less able. Family is a source of happiness of life that is primary for children, (Wahyuni et al., 2018) causes or factors of the family that affect the well-being of the subjective a child needs to be investigated or known example relationship positive between father, mother, son and brothers birth in the home.

Families who come from low-income families may be experiencing difficulties in terms of children's education (Sobur, 2013). In families with relatively more minor economic conditions, maybe the cause of the Child malnutrition and Children's needs may not be met. In addition, the factor of economic deficiency causes the atmosphere at home to be gloomy, which in turn causes the loss of children's enthusiasm to learn. Many families do not continue their children's education to the higher education level due to the difficulties in terms of the cost of education they cannot reach. As a result, many of them have a low level of education, which weakens the power of competitiveness with the world outside. Society is seen next to the eye due to the low level of education (Willis, 2018). The government has tried various ways to eradicate poverty, yet poverty is still out of control, and there are still many low-income families in this country.

Another thing that affects the children's subjective well-being is that high life satisfaction is a feeling the effects are positive and the lack/absence feeling/affect - affect negatively perceived. According to (Arbiyah et al., 2007), joy or happiness, affection, and pride or gratitude are factors that increase positive affect from within individuals, such as optimistically looking at the future. Furthermore (Ariati \& Hyoscyamina, 2017) said people who are optimistic about the future feel happier and satisfied with their lives. Individuals who positively evaluate themselves will have good control over their lives, so they have positive dreams and hopes about the future. Based on these opinions, it is necessary to increase the Children optimism in looking at the future to improve the welfare of subjectivity. This indicates that even though they come from poor families, children have high tenacity in facing learning difficulties. Logically, learning difficulties can cause a child's failure in education if he is not able to be tenacious in overcoming these difficulties. With the hope of success in terms of education, children who come from poor families try to be tenacious in overcoming their difficulties in learning. So that failure is not a fear for him to achieve success.

The learning difficulties of children who come from low-income families generally lie in the family's economic condition. According to (Maslihah, 2017) the economic situation of a low-income family will lead to a lack of learning tools, lack of funds provided by parents, not having a good place to study. Then the statement (A'la, 2016) poor economic conditions will lead to 1) lack of learning tools, 2) lack of funds provided by parents, and 3) not having an excellent place to study. However, the culture foster the ideal of providing fulfilling children's needs both physical and psychological needs, according to the stage and development tasks. (Maccoby \& Martin, 1983) mentions two dimensions that distinguish parents' behavior towards their children: 1) Parental responsiveness, namely the degree to which parents respond to children's needs through acceptance and support. 2) 
The demands of parents (parental demandingness) are how parents' expectations and demands on their children's responsible behavior.

The authoritative type reflects a parenting culture where parents are disciplined and firm, demanding and supervising, but also consistent, loving, and communicative in meeting the needs of their children. Authoritarian parents who tend to be high in demand children to behave responsibly, but do not listen to the child, do not give an example or example that can be followed by children so that children are often caught in a situation that can not be controlled (Sulastri \& Ahmad, 2017).

The indulgent type is characterized by a lack of consistency between parents in giving rules and demanding children be responsible for their behavior. However, parents still give enough attention and affection. This type is more often known as spoiling children. Spoiling a child to follow throughout the wishes of children significantly affect the development of moral and value of religion the child badly by the results of the study (Inawati, 2017) strategy to develop morals and values of religion of children with patterns of parenting prophet who is not authoritarian or obey all the wishes of children.

While the indifferent type is often known as ignoring children, they are also not required to be responsible for their behavior. Parents had a life apart from their children, so children are free without control (Fletcher et al., 2008). In the four types, parents are expected to balance demands and responsibilities as contained in the authoritative type, although the terms and conditions still apply. It is not likely to occur in child care just using one approach, but it needs to use all approaches proportionally according to the child's condition (Mehdizadeh et al., 2020). It is undeniable that there is a tendency for one parenting approach to be more dominant than other parenting cultural patterns.

\section{CONCLUSION}

Parenting culture in the poorest families in improving subjective well-being is not optimal early childhood. Starting from the results of the research, the government has a significant role in supporting morally and materially in improving the subjective welfare of early childhood because in the hands of the children, the future of the nation, especially for agencies/services/ministers of women's empowerment and child protection. Then parents and teachers are advised to take part in training or education to increase their knowledge in early childhood care.

\section{REFERENCES}

Badan Pusat Statistik. (2019). Berita resmi statistik. Bps.Go.Id.

A’la, R. (2016). Perhatian Orang Tua Dan Motivasi Belajar Siswa. Jurnal Madaniyah.

Arbiyah, N., Imelda, F. N., \& Oriza, I. D. (2007). Hubungan bersyukur dan subjective well being pada penduduk miskin. Jurnal Psikologi Sosial.

Ariati, J., \& Hyoscyamina, D. E. (2017). Development and initial validation of emotional support and achievement motivation scales as a part of the redi-Space assessment. Pertanika Journal of Social Sciences and Humanities.

Badan Pusat Statistik. (2017). STATISTIK KESEJAHTERAAN RAKYAT. ABA Journal. https://doi.org/10.1002/ejsp.2570

Camfield, L., Crivello, G., \& Woodhead, M. (2009). Well-being research in developing countries: Reviewing the role of qualitative methods. Social Indicators Research. https://doi.org/10.1007/s11205-008-9310-z

Crider, C. (1981). Children's conceptions of the body interior. New Directions for Child and Adolescent Development. https://doi.org/10.1002/cd.23219811405

Dambi, J. M., Jelsma, J., Mlambo, T., Chiwaridzo, M., Tadyanemhandu, C., Chikwanha, M. T., \& Corten, L. (2016). A critical evaluation of the effectiveness of interventions for improving the well-being of caregivers of children with cerebral palsy: A systematic review protocol. Systematic Reviews. https://doi.org/10.1186/s13643-016-0287-4

Departemen Sosial RI. (2005). Anak Jalanan. Sosiologi.

Diener, E., Lucas, R. E., Diener, E., \& Larsen, R. J. (2009). Assessing Well-Being. The Science of Wellbeing The Collected Works of Ed Diener. https://doi.org/10.1007/978-90-481-2354-4 
Diener, E., Lucas, R. E., \& Oishi, S. (2000). Diener-Subjective_Well-Being.pdf. In The Science of Happiness and Life Satisfaction. https://doi.org/10.1093/oxfordhb/9780195187243.013.0017

Elisabet, H. (2010). Psikologi Perkembangan Suatu Pendekatan Sepanjang Rentang Hidup. In Erlangga.

Fatkhurohmah, D., Karim, M. B., \& Nisa, T. F. (2019). Kelekatan Anak Keluarga Tenaga Kerja Wanita. AL-ATHFAL: JURNAL PENDIDIKAN ANAK. https://doi.org/10.14421/alathfal.2019.52-06

Fletcher, A. C., Walls, J. K., Cook, E. C., Madison, K. J., \& Bridges, T. H. (2008). Parenting style as a moderator of associations between maternal disciplinary strategies and child well-being. Journal of Family Issues. https://doi.org/10.1177/0192513X08322933

Fomby, P., \& Cherlin, A. J. (2007). Family instability and child well-being. American Sociological Review. https://doi.org/10.1177/000312240707200203

Fuad, M. (2017). Psikologi Kebahagiaan Manusia. KOMUNIKA: Jurnal Dakwah Dan Komunikasi. https://doi.org/10.24090/komunika.v9i1.834

Henslin, J. M. (2017). Chapter 6: Deviance and Social Control. Essentials of Sociology A Down-ToEarth Approach.

Hidayati, L. (2016). Model Pengasuhan Alternatif Pada Dual-Career Family. Al Athfal: Jurnal Pendidikan Anak.

Inawati, A. (2017). Strategi Pengembangan Moral dan Nilai Agama Untuk Anak Usia Dini |ALATHFAL : JURNAL PENDIDIKAN ANAK. Al-Athfal: Jurnal Pendidikan Anak.

Kahneman, D., \& Krueger, A. B. (2006). Developments in the measurement of subjective well-being. In Journal of Economic Perspectives. https://doi.org/10.1257/089533006776526030

Koivumaa-Honkanen, H., Honkanen, R., Viinamäki, H., Heikkilä, K., Kaprio, J., \& Koskenvuo, M. (2001). Life satisfaction and suicide: A 20-year follow-up study. American Journal of Psychiatry. https://doi.org/10.1176/appi.ajp.158.3.433

Maccoby, E. E., \& Martin, J. (1983). Socialization in the Context of the Family: Parent-Child Interaction. In Handbook of Child Psychology: \{Vol\}. 4. \{Socialization\}, Personality, and Social Development.

Mahyatun, B. (2019). Preventing Bullying Through Group Counseling. https://doi.org/10.2991/icoie-18.2019.17

Maslihah, S. (2017). Faktor Yang Mempengaruhi Kesejahteraan Subyektif Anak Didik Lembaga Pembinaan Khusus Anak. Jurnal Psikologi Insight. https://doi.org/10.5281/ZENODO.824623

McCormick, R. (2017). Does Access to Green Space Impact the Mental Well-being of Children: A Systematic Review. In Journal of Pediatric Nursing. https://doi.org/10.1016/j.pedn.2017.08.027

Mehdizadeh, A., Nematy, M., Vatanparast, H., Khadem-Rezaiyan, M., \& Emadzadeh, M. (2020). Impact of Parent Engagement in Childhood Obesity Prevention Interventions on Anthropometric Indices among Preschool Children: A Systematic Review. In Childhood Obesity. https://doi.org/10.1089/chi.2019.0103

Mizkan, H., Kamaliah, K., \& Agusti, R. (2015). Analisis Kinerja Pengelolaan Keuangan Daerah Dan Pengaruhnya Terhadap Tingkat Kemiskinan Di Kota Pekanbaru. SOROT. https://doi.org/10.31258/sorot.10.1.3209

Nurwati, N. (2008). Kemiskinan: Model Pengukuran, Permasalahan dan Alternatif Kebijakan. Jurnal Kependudukan Padjadjaran.

Prawoto, N. (2008). Memahami Kemiskinan Dan Strategi Penanggulangannya. Jurnal Ekonomi \& Studi Pembangunan. https://doi.org/10.18196/jesp.9.1.1530

Putro, K. Z. (2016). Pengaruh Pola Asuh Dan Interaksi Teman Sebaya Terhadap Kecerdasan Emosional Anak Di Ra Arif Rahman Hakim Yogyakarta. Al Athfal: Jurnal Pendidikan Anak.

Santrock. (2003). Life-Span Development: Perkembangan Masa Hidup. In Erlangga. https://doi.org/10.1109/ciced.2018.8592188

Sobur, A. (2013). Psikologi Umum (Dalam Lintas Sejarah). In Bandung: CV Pustaka Setia. https://doi.org/10.1017/CBO9781107415324.004

Steinberg, L. (2005). Cognitive and affective development in adolescence. In Trends in Cognitive Sciences. https://doi.org/10.1016/j.tics.2004.12.005

Sulastri, S., \& Ahmad, T. (2017). Peran Orang Tua Dalam Pendidikan Anak Usia Dini Dintinjau Dari Latar Belakang Pendidikan. Raudhatul Athfal: Jurnal Pendidikan Islam Anak Usia Dini. https://doi.org/10.19109/ra.v1i1.1526 
Suryawati, C. (2005). memahami kemiskinan secara multidimensional. Jmpk.

Taufiq. (2012). Positive Psychology: Psikologi Cara Meraih Kebahagiaan. Prosiding Seminar Nasional Psikologi Islami.

Valois, R. F., Zullig, K. J., Huebner, E. S., \& Drane, J. W. (2004). Physical activity behaviors and perceived life satisfaction among public high school adolescents. Journal of School Health. https://doi.org/10.1111/j.1746-1561.2004.tb04201.x

Wahyuni, S., \& Reswita. (2018). Low-income Family Environment: Subjective Well-Being and Children Learning Motivation. IOP Conference Series: Earth and Environmental Science, 175, 012103. https://doi.org/10.1088/1755-1315/175/1/012103

Wahyuni, S., Reswita, R., \& Filtri, H. (2018). Subjectif Well-Being Anak Yang Berasal Dari Keluarga Berstatus Ekonomi Sosial Rendah. Lectura: Jurnal Pendidikan. https://doi.org/10.31849/lectura.v9i2.1605

Willis, K. (2018). The sustainable development goals. In The Routledge Handbook of Latin American Development. https://doi.org/10.4324/9781315162935-11

Yuniana. (2011). Kesejahteraan subjektif pada yatim piatu (Mustadh'afin). Fakultas Psikologi UAD. https://doi.org/10.1017/CBO9781107415324.004 